\title{
Wildlife Crime: A Crime of Hegemonic Masculinity?
}

\author{
Ragnhild Sollund $\mathbb{D}$ \\ Department of Criminology and Sociology of Law, University of Oslo, 0130 Oslo, Norway; \\ ragnhild.sollund@jus.uio.no
}

Received: 8 May 2020; Accepted: 28 May 2020; Published: 5 June 2020

\begin{abstract}
Scholarship within green criminology focusing on crimes and harms against nonhuman animals has been increasing. Little attention, however, has been directed at the gendered aspects of these crimes. For example, why is it that the great majority of offenders involved in wildlife trade and the illegal killing of endangered predators are male? The aim of this article is to fill the gap in the literature, relying on confiscation reports from Norwegian Customs of nonhuman animals-most of whom are listed in CITES (the Convention on International Trade in Endangered Species of Fauna and Flora) —as well as an analysis of verdicts in cases in Norwegian courts of "theriocides" (animal murders) of large predators. This article will assess the number of men and women involved in these crimes and harms, and will present some trends of theriociders. This article will employ ecofeminist and masculinities theories to better understand the gendered dynamics involved in wildlife trafficking and the theriocides of large carnivores.
\end{abstract}

Keywords: ecofeminism; green criminology; hegemonic masculinity; hunting crimes; wildlife trafficking

\section{Introduction and Theoretical Approach: Green Criminology, Ecofeminism and Hegemonic Masculinity}

During the past decade, an increasing amount of green criminology scholarship has focused on crimes and harms against nonhuman animals, particularly "free born nonhuman animals ${ }^{1}$ - or so-called "wildlife." These studies encompass legal and illegal hunting (Nurse 2015; Sollund 2015, 2017b), and "wildlife" trafficking (WLT), with a particular concern for species that are threatened with extinction (e.g., Goyes and Sollund 2016; Leberatto 2016; Maher and Sollund 2016; Schneider 2012; Sollund 2011, 2012a, 2012b, 2013a, 2013b, 2016, 2019; Van Uhm 2016; White 2018; Wyatt 2011, 2013). Less attention has been paid to the offenders, apart from categorizations according to their role in such crimes (e.g., Nurse 2015; Wyatt 2013), although Nurse (2015) and Sollund (2019) underline that men are more likely to commit "wildlife" crimes than women. In addition, although green criminology evolved, in part, from ecofeminist insights and should incorporate the perspectives of this approach, this theoretical line of scholarship has not been explored to the extent that it might (for exceptions, see, e.g., Lane 1998; Lynch and Stretsky 2003; Sollund 2008, 2012a, 2019; Taylor and Fitzgerald 2018).

This is a regrettable void which I aim to reduce, since androcentric, Eurocentric, racist and speciesist ${ }^{2}$ ideologies have been and still are institutionalised and, as such, are ingrained into the

1 Some notes about terminology are in order since words and discourse are in constant interplay with our perception of the world, and as such sustain speciesist practices and attitudes. I have chosen the term "nonhuman animal," although I acknowledge it has shortcomings, just like the word "animal" makes a distinction between the human animal and all the other animal species. "Wildlife" is also problematic insofar as it is a mass term that refers to both animals and plants, and fails to consider the individual intrinsic value of either. This said, for simplicity, I retain these terms in this article, but keep "wildlife" in apostrophes to illustrate the shortcomings of such wording.

2 Speciesism refers to the ways in which humans discriminate animals on the basis of species, essentially because they are not human. It is analogous to other 'isms' as racism, sexism, ageism and ableism, although the victims of speciesism are always nonhuman. 
fabric of scientific research constituted as "neutral" and "objective" (Harding 2004; Haraway 1988; Sollund 2017a). Some feminists in the humanities and social sciences have questioned how women had been portrayed as appendices to men (De Beauvoir and Parshley 1953) and, as such, considered of little interest by male scholars and more generally; the oppression of women being doxic (Bourdieu 1995). As gender theory developed, including theories of hegemonic masculinities (Connell 2005) and intersectionality - the relationships among multiple dimensions and modalities of social relations and subject formations (McCall 2005)_one came to realize that not only are there multiple masculinities, but also multiple femininities. Intersectionality theory has been applied most widely to study women, such as how their gender- or sex-based oppression may occur in conjunction with their class, ethnicity, race and citizenship status (e.g., Joseph 2010). Intersectionality may also be employed to discuss the plight, for example, of male migrant nurses (Seeberg 2012) and, as applied in this article, to discuss offenders, such as why men in rural areas may adopt gender-based or masculine strategies which may impact their sociolegal/illegal behaviour. For example, experiences of being ignored by the central authorities may encourage them to turn to wildlife crimes, whereby both protest (Von Essen et al. 2014) and hegemonic masculinities are expressed. How may the 'wildlife' crimes of men be analysed not only in view of, for example, traditional theories of social exclusion, but also in view of gender theory?

Patterns of abuse and oppression have their source in androcentric culture and power (Adams 1996; Gålmark 2008, 2016; Kheel 2008; Nibert 2002, 2013) and, as will be shown, men are also the most frequent perpetrators of harms/crimes against free-born nonhuman animals. The combination of a lack of empathy and self-ascribed rights to commit violent, abusive acts, such as those legitimised through legal hunting practices, may be very destructive on a large scale. From an ecofeminist perspective (Donovan and Adams 1996; Gaard 1993; Kheel 2008; Sollund 2013b, 2019), the ideals that govern our treatment of nonhuman animals in nature are ingrained by patriarchal values through which, for example, a boy's killing of an animal while hunting is regarded as a rite of passage that turns him into a man, thereby glorifying the act of theriocide (Beirne 2014; Connell 2005; Fine 2000; Kheel 2008, pp. $49,125,129) .{ }^{3}$ Indeed, one rationale for nature conservation is to provide sufficient prey for male hunters, as Theodore Roosevelt argued (Kheel 2008, chp. 3). This may still be the case in the context of trophy hunting, undertaken for supposed "conservation purposes", whereby foreign hunters pay hefty sums to travel to Africa in order to kill elephants, giraffes, lions, and rhinos; the money they pay is then allegedly used to "preserve" other species (Duffy 2000; Wall and McClanahan 2015). Similarly, Aldo Leopold, the conservationist and environmentalist, saw hunting as contributing to the moral improvement of the human race (read: men) (Kheel 2008).

In contrast, David Nibert (2013) argues that humans' domesecration ${ }^{4}$ and killing of animals have contributed greatly to moral decay and to societies that encourage warfare and slavery. Kheel (2008, pp. 16-17) likewise argues that the dominance and exploitation of the natural world is based on gendered ideas and hegemonic masculine ideologies. I will use the examples of WLT and predator theriocides ${ }^{5}$ as evidence of a hegemonic and harmful masculinity ${ }^{6}$ that permeates not only crimes against "wildlife", but most other harmful aspects of society, including warfare and oppression of nonhuman animals and women.

3 One can also ask whether the increase in female hunters in Norway now $15 \%$ and on the rise (Sollund $2017 \mathrm{~b}$ ) is related to female hunters' belief that, through hunting, they will become more equal to men, and thus superior to other women.

4 By domesecration, David Nibert (2013) understands the systemic practice of violence in which social animals are enslaved and biologically manipulated, resulting in their objectification, subordination and oppression.

5 Piers Beirne develops this concept in an article from 2014, using: theriocide' as the name for those diverse human actions that cause the deaths of animals. Like the killing of one human by another, theriocide may be socially acceptable or unacceptable, legal or illegal. It may be intentional or unintentional and may involve active maltreatment or passive neglect. Theriocide may occur one-on one, in small groups or in large-scale social institutions. The numerous and sometimes intersecting sites of theriocides include intensive rearing regimes; hunting and fishing; trafficking; vivisection; militarism; pollution; and human induced climate change (Beirne 2014, p. 49).

6 Portions of this article appear in Sollund (2019). 
Before proceeding, a word on hegemonic masculinity is in order. Hegemony works here, in part, through the production of exemplars of masculinity—symbols that have authority and meaning despite the fact that most men and boys do not live up to them fully (Connell and Messerschmidt 2005). While only a minority of men might engage in hegemonic masculinity, it still sets normative standards: "It embodie[s] the currently most honoured way of being a man, it require[s] all other men to position themselves in relation to it, and it ideologically legitimate[s] the global subordination of women to men" (Connell and Messerschmidt 2005, p. 832).

Hegemony entails ascendancy achieved through culture, institutions, and persuasion (Connell and Messerschmidt 2005); patriarchal values, as manifested through hegemonic masculinity, become ingrained attitudes and practices-habitus-of the large majority of men as doxic "values" (Bourdieu 1995; Sollund 2012a). Masculinity, feminist and gender theory (e.g., Connell and Messerschmidt 2005), although present in feminist criminology (e.g., Burgess-Proctor 2006; Smart 2013) and criminology, more generally, has been incorporated only occasionally into green criminology's inquiries. In line with ecofeminist thought, the question to be asked is whether normative standards for how to do gender, and more specifically, hegemonic masculinity (Connell and Messerschmidt 2005), explain why men are the large majority of offenders of "wildlife" crimes.

My intention in this article, then, is to expand green criminology and the study of "wildlife" crimes by reviving the line of criminological inquiry inspired by ecofeminism and theories of hegemonic masculinity from the 1990s. Initially, the concept of hegemonic masculinity was used to study and explain the overrepresentation of men in "conventional" or violent crimes, but it has since been re-examined (Connell and Messerschmidt 2005)—and it is this reformulated concept that I rely on herein. In their assessment of the validity of the concept, Connell and Messerschmidt (2005) state that, in principle, the concept of hegemonic masculinity is by and large still usable, as it presumes the subordination of nonhegemonic masculinities-a process that has been documented in many settings. Additionally, well supported, they say, is the idea that the hierarchy of masculinities is relational and a pattern of practices and hegemony, not only simple domination based on force, and not just role expectations of an identity (p. 832). "Cultural consent, discursive centrality, institutionalization, and the marginalization or delegitimization of alternatives are widely documented features of socially dominant masculinities" (p. 836). In what follows I present an overview of "wildlife" crimes in Norway and their legal framework. Thereafter, I turn to the methodology applied in the research done for this article, before I discuss findings.

\section{WLT and Predator Theriocides in Norway: An Overview}

In this article, I focus on two kinds of crimes and harms against free born nonhuman animals: (1) WLT; and (2) theriocides (Beirne 2014) of endangered predators.

With respect to the first of these (WLT), the purported aim of the Convention on International Trade in Endangered Species of Fauna and Flora (CITES) is to ensure that the international trade of wild animals and plants does not threaten their survival (see https://cites.org/). Under the convention, the import, export, re-export and introduction of species covered by CITES must be authorized through a licensing system. Each party to CITES must designate one or more management authorities in charge of administration the licensing system and one or more scientific authorities to advise that party on the effects of trade on the status of the species. Species covered by CITES are listed in three Appendices, according to the degree of protection that they need. Species included in Appendix I are those threated with extinction; trade in these species is permitted only in exceptional circumstances. Appendix II lists those species that are not necessarily threatened with extinction, but in which trade must be controlled in order to avoid "use" that is incompatible with their survival. Appendix III contains species that are protected in at least one country-which has asked other parties to CITES for their assistance in controlling the trade. 
The parties to CITES (currently 183), which includes Norway, must ensure that the obligations to the trade regulations of the convention are fulfilled through the implementation of national legislation and enforcement in their own jurisdictions. Norway has attempted to satisfy its requirements under CITES through a number of different laws: the Wildlife Law $^{7}$ (Lov om jakt og fangst av viltet—viltloven); the Nature Diversity Act (Naturmangfoldsloven); ${ }^{8}$ the Law of Import and Export Regulation from 6 June 1997 (Lov om innførsle og utførsleregulering) ${ }^{9}$ and the laws concerning environmental protection of Svalbard and Jan Mayen. ${ }^{10}$ Which laws apply are somewhat subject to prosecutorial and judicial discretion, with consequences for enforcement that may affect the severity with which CITES is regarded by the judicial system (Sollund 2019).

The second category refers to the illegal killing of animals of large, endangered predator species (brown bears, lynx, wolverines, wolves). This is of concern not only because of the harm to these animals (see Sollund 2015, 2016, 2017b, 2019) but because Norway is a party to the Bern Convention on the Conservation of European Wildlife and Natural Habitats ("Bern Convention") ${ }^{11}$ —a convention with 51 parties that aims to protect endangered species and their habitats. The illegal killing of endangered predators in Scandinavia constitutes the largest threat to those species' survival (Liberg et al. 2012). However, Norway's fulfilment of its duties under the Bern Convention is also a problem. In Norway the enforcement of this convention is (also) based in the Wildlife Law and the Nature Diversity Act. While hunting the endangered animals is illegal, there are a large number of available exceptions. For example, when licensed wolf hunts are organised, a great number of hunters regularly enlist to participate, indicating the enthusiasm Norwegian hunters have for the opportunity to kill this mythic animal (Sollund 2017b). I will return to this later in the article.

There is much controversy surrounding the ways in which Norway has attempted to fulfil its obligations to protect the wolves (Skogen et al. 2013) and to the Bern Convention. For example, an analysis of Norwegian wolf policy in relation to the Bern Convention by Trouwborst et al. (2017) contends that Norway breaches the requirements of the convention by keeping the species at the brink of extinction. The standing committee of the Bern Convention has clarified that wild species which have an unfavourable conservation status (particularly those listed in Appendix II of the convention, like the Norwegian wolf) may require special conservation efforts to acquire a population level which corresponds to their ecological requirements, as stated in Article 2 of the convention (Trouwborst et al. 2017, p. 160). Rather than helping the endangered species to flourish, however, Norwegian policy is the opposite (Sollund 2017b; Trouwborst et al. 2017). The Wildlife Law bans the hunting of these species, but the state nonetheless allows for licensed hunting of the wolves on a regular basis. In the license period from 2017-2018, permission was granted to shoot 50 wolves in Norway, out of a total population of a of maximum 84 wolves. In addition, Norway allows quota hunts for lynx, and the authorities kill wolverine pups and mothers in the dens, in order to keep their populations low. Farmers easily get permission to kill bears and wolves to protect unherded "livestock" and other human interests (Sollund 2019). As a consequence, the World Wildlife Foundation (WWF Norway) has brought the Norwegian state to court on more than one occasion. The last sentence in favor of the state occurred in Oslo District Court May 2018 and was appealed to Borgarting Court of Appeal by WWF Norway. This Court decision fell on 29 January 2020, and will not be analysed herein. The state was partly convicted and both parties, the state and WWF Norway have appealed the decision to the Supreme Court. This court decision is, at the moment of writing ${ }^{12}$, pending.

\footnotetext{
https://lovdata.no/dokument/NL/lov/1981-05-29-38.

https://lovdata.no/dokument/NL/lov/2009-06-19-100.

http://lovdata.no/dokument/NL/lov/1997-06-06-32.

10 Lov av 15 juni 2001 nr. 79 om miljøvern på Svalbard (svalbardmiljøloven) § 26 annet ledd, lov av 17 juli 1925 nr. 11 om Svalbard § 4, samt lov av 27 februar $1930 \mathrm{nr}$. 2 om Jan Mayen $\S 2$.

11 https://www.coe.int/en/web/bern-convention.

128 May 2020.
} 


\section{Methodology}

I compiled and produced the data for this project in Norway between November 2010 and December 2017. ${ }^{13}$ Data included interviews with customs officials (directorate and border) (4), police officers (4), Norwegian Environment Agency officials (2), reptile traffickers/keepers (5 (3 male, 2 female) $){ }_{1}^{14}$ and veterinarians (2). Several of the interviews with control agencies included several interviewees. In addition, I had many telephone conversations with police officers concerning cases under investigation. Furthermore, I had access to customs' confiscation reports concerning "wildlife" trafficking and verdicts concerning the same. Some of these data are also presented and discussed in Sollund (2019).

In total, I collected 125 seizure reports. The Norwegian Customs and Tax Directorate have provided these to me, with the permission of The Norwegian Social Science Data Services (NSD). It must be emphasized that these seizures likely represent only the tip of the iceberg because CITES is not a high priority for Norwegian Customs, who have targets for drugs seizures but not for CITES (Sollund 2013a; Runhovde 2015). In addition to these data, during this project I gained access to more than 800 police case files, which included cases primarily relating to the illegal trafficking and keeping of reptiles. These data will be used as background, although thorough analyses of these data remain. They are therefore not included in the table, and will be subjected to thorough scrutiny in future research. The overall tendency in these are, nonetheless, that only a few of these cases include female offenders. ${ }^{15}$ These case files were also accumulated with the permission of the Norwegian Social Science Data Services (NSD) as well as the Higher Prosecution Authorities (Riksadvokaten).

Finally, I analysed ten verdicts from the cases involving seizures or other trafficking and approximately thirty sentences concerning other "wildlife" crime cases, such as illegal wolf killing. The ten verdicts concerning seizures and trafficking were cases that were treated in courts during the data collection period that I followed from the seizure to conclusion in the judicial system. The "wildlife" crimes cases were selected from the Norwegian data base Lovdata ${ }^{16}$, based on search terms that could lead me to these sentences. This database contains sentences from Norwegian courts of principal interest. Sentences can be found on the basis of search terms. I used search terms such as "lynx", wolf", "bear", or "wolverine", as well as relevant legislation used in these cases, such as the law of biodiversity and the wildlife law. I have during the past decade done analyses of these sentences. From the sentences, I have subjected the most relevant to in-depth analyses. Of these, several have been appealed from the District Court and at times through Courts of appeal ending in the Supreme Court (Sollund 2015; Sollund 2016; Sollund 2017b). The analyses of verdicts for illegal killing of endangered predators in Norway is a project I have run parallel to the research on WLT. In what follows, I sketch out some features of the main categories of WLT, with a special focus on reptile trafficking and collecting, before presenting some significant trends in predator theriocides. Based on the data, these three categories of "wildlife" crimes are the most common, and clearly invite for a gender analysis.

\section{Categories of Trafficking Cases in Norway}

The seizure reports concerning cases spanning the years 2007-2017 from Norwegian Customs present a diverse picture of animal trafficking victims and perpetrators. They involve three categories of nonhuman animals/products: (1) live CITES-listed nonhuman animals, including amphibians,

13 Qualitative interviews and the information they provide depend on cooperation between researcher and interviewee. As such, I see such data as the product of a collaboration, rather than just a matter of collection by the researcher.

14 Keeping "exotic" reptiles was generally banned in Norway until 15 August 2017, when the Food Safety Authority permitted 19 species, of which 15 are listed in Appendix II of CITES or on lists by the International Union for the Conservation of Nature (IUCN).

15 These data will be subject to a thorough analysis in the research project Criminal Justice, wildlife conservation and animal rights in the Anthropocene (CRIMEANTHROP), funded by the Research Council Norway (2019-2023).

16 https://lovdata.no/. 
annelids, birds, mammals and mollusks; (2) nonhuman animal products, including stuffed nonhuman animals, and (3) non-CITES, or unknown, live nonhuman animal products (and stuffed nonhuman animals). The cases can be organised according to the motivation of the offenders for the trafficking: (1) "pet" traders; 17 (2) businessmen; (3) collectors; (4) tourists; (5) consumers of traditional Asian medicine (TAM) or traditional Chinese medicine (TCM) (see Van Uhm 2016); (6) sport fishers and (7) trophy hunters.

Within the three categories of seizures, offenders have trafficked live nonhuman animals, such as a Bengal cat, parrots and reptiles to keep them as 'pets' ${ }^{18}$. Nonhuman animals are also trafficked by businesspersons who want to profit from the 'pet wildlife' trade. The (former) head of the standing committee of CITES, working at the Norwegian Environment Agency, added to this category of 'professionals', other profiteers, for example including internet-based companies that make money by not following the rules, and large commercial actors selling medicinal products.

Many offenders also become involved in the WLT based on impulse. For example, they buy a tortoise in a market on the spur of the moment and then cross state lines with the tortoise in his/her pocket. Others, however, engage in WLT in a more planned fashion: reptile traffickers, for example, might drive two cars in tandem, with the second one bringing the animal across the border only if the first car drives through unhindered (Sollund 2013a). Many traffickers in the 2nd category are tourists who buy skins and products, often unaware of the illegality and harms of what they are doing. Nonhuman animals or their parts are also trafficked as medicinal products, reflecting the place traditional Asian/Chinese medicine [TAC/TCM] has in wildlife trafficking (e.g., Van Uhm 2016). Another increasingly frequent seizure, in 2017 the dominant one, is Jungle Cock Necks because sport fly fishers use the feathers to bind flies.

Collectors are important perpetrators in that they buy animals/animal products (e.g., bird eggs, ivory, pelts) to add to their collections. Trophy hunters will also bring home or have sent home the carcasses of their victims.

Table 1 below shows the gender of the trafficker. For all three categories of offense, the large majority of the offenders are male.

Table 1. Gender of traffickers in the three categories.

\begin{tabular}{|c|c|c|c|c|c|c|c|c|c|c|c|c|c|}
\hline & 2007 & 2008 & 2009 & 2010 & 2011 & 2012 & 2013 & 2014 & 2015 & 2016 & 2017 & TOTAL & $\%$ \\
\hline \multicolumn{14}{|c|}{ Category 1} \\
\hline Male & 0 & 5 & 1 & 3 & 5 & 3 & 3 & 4 & 0 & 2 & 0 & 26 & 89.7 \\
\hline Female & 0 & 0 & 1 & 0 & 0 & 1 & 0 & 0 & 0 & 1 & 0 & 3 & 10.3 \\
\hline \multicolumn{14}{|c|}{ Category 2} \\
\hline Male & 1 & 3 & 4 & 1 & 8 & 6 & 1 & 11 & 17 & 14 & 3 & 69 & 88.5 \\
\hline Female & 0 & 1 & 0 & 0 & 2 & 1 & 0 & 2 & 2 & 1 & 0 & 9 & 11.5 \\
\hline \multicolumn{14}{|c|}{ Category 3} \\
\hline Male & 0 & 2 & 1 & 2 & 0 & 4 & 0 & 1 & 1 & 0 & 0 & 11 & 91.6 \\
\hline Female & 0 & 0 & 0 & 1 & 0 & 0 & 0 & 0 & 0 & 0 & 0 & 1 & 8.3 \\
\hline Total & 1 & 11 & 7 & 7 & 15 & 15 & 4 & 18 & 20 & 18 & 3 & 119 & $\begin{array}{l}89.1 \text { male } \\
8.9 \text { female }\end{array}$ \\
\hline
\end{tabular}

According to these reports, nearly $90 \%$ of trafficking offenders in Norway are men, suggesting that, at least in Norway, this is a gendered crime. Men are, however, large majority of the offenders of all registered crimes. In this sense, then, WLT is no different from other crimes. For example, according to

17 "Pet" is an anthropocentric term insofar as it implies that the purpose of the nonhuman animal is to only serve instrumentally as a companion to humans. For simplicity, however, I retain the term, but with apostrophes: "pet".

18 In six of the cases from the 125 confiscation reports, the gender of the trafficker is not mentioned. 
the official bureau of statistics, Statistics Norway's ${ }^{19}$ overview of all charges for crime in 2016, the total number of persons charged was 169,496; 145,031 were brought against men and 24,465 were brought against women, constituting approximately $14 \%$ of the total. ${ }^{20}$

In the roughly thirty verdicts that I have examined from Norwegian courts for the illegal killing of endangered large predators, all offenders are male (see also Sollund 2015, 2016, 2017b). Another common feature of these cases is that in most cases, these crimes are committed by means of firearms: the offenders have obtained permission to keep/use a firearm, usually a rifle, and which, in other circumstances, they may use to kill other nonhuman animals, such as foxes or elks, within the limits of the law. The weapon may also have been used to legally kill endangered predators when the offenders have enlisted for state licensed hunts, such as those involving lynx and wolves.

\section{Trends in Large Predator Theriociders}

Most offenders kill by means of firearms, but the extent of their proficiency in using them varies. I note this because in all the licensed hunts, there are numerous incidents of shootings in which a nonhuman animal is injured and suffers significantly before $\mathrm{s} /$ he is finally killed or dies as a consequence of the shot; this is also the case in illegal theriocides ${ }^{21}$ (Sollund 2017b). This does not mean that a firearm is always involved in such theriocides, however. In the Scandinavian countries, the use of poisoned bait is a well-known tactic to kill unwanted predators (Liberg et al. 2012). Using radio tracking, researchers estimated that between 1999 and 2006, half of all deaths among wolves was caused by illegal hunting, amounting to $136 \pm 56$ wolves having been killed in Scandinavia in this period $^{22}$ (see (Sollund 2015, 2017b) for an analysis of predator theriocides convictions). Although poisoning is a crime that may be difficult to detect, there are still convictions for this kind of crime. ${ }^{23}$

There are also, though, many other ways to kill endangered predators, such as digging out a den of a mother wolverine and her pups, and killing them. This is the method used by the state to keep the number of wolverines down, and individuals have also applied for the license to kill wolverines legally (Sollund 2015).

The most frequent modus operandi in these theriocides-at least, those that result in court cases $^{24}$-involves shooting the nonhuman animal and claiming that it was in self-defense or undertaken in response to an emergency in order to protect "livestock." 25 Every spring, two million sheep are released to pasture, leaving them vulnerable to the 300-400 large predators in the country. ${ }^{26}$

Claims of self-defence or emergency to protect cows, hens, pigs, and sheep, among other nonhuman animals, are often made in Norwegian courts, and state-initiated killing of predators is often undertaken with the same goal in mind-to protect "livestock" (Sollund 2015, 2016, 2017b; Trouwborst et al. 2017). A claim of self-defence or emergency may, nonetheless, mask other motivations, such as hatred; defending "livestock" may be more a matter of protecting one's capital/property than a reflection of concern for the individual lives of the cows, hens, pigs, sheep, etc. see, e.g., (Nibert 2013); for a more in-depth discussion, and (Sollund 2015, 2016).

19 https://www.ssb.no/sosiale-forhold-og-kriminalitet/statistikker/lovbrudde/aar.

20 Whether this is also caused by under control and thus lack of detection of crimes committed by women due to normative gendered expectations, is a discussion I must leave aside here.

21 For a thorough examination of this distinction and its importance, see (Sollund 2016).

22 https://www.nina.no/english/News/News-article/ArticleId/641.

23 For example, in 2001, an offender was sentenced to twenty-one days in prison for using poison to kill "wildlife." His conviction and sentence were upheld in the Norwegian Supreme Court [LE-2001-246 M].

24 Many wolf theriocides are never detected and thus never result in arrest, prosecution, conviction and sentencing (Liberg et al. 2012).

25 For example, a man who shot a bear in 2003 claimed that he had done so in order to protect his pigs (Sollund 2015). He was convicted, however, and received a twenty-one day suspended sentence [LH-2004-99118].

26 His danger is increased when the Norwegian authorities, as they did in 2017, exterminate packs of wolves that live on elk. Younger wolves, who cannot hunt elk on their own, therefore prey on sheep. 


\section{Gender-Based Analysis of Offender Typologies}

In the following I discuss the three most outstanding categories in my material, which most invite an analysis in terms of hegemonic masculinity and intersecting dimensions, such as marginalization and gender normativity. These are: (1) The traffickers and keepers of 'exotic' reptiles, (2) the collectors of 'wildlife', and (3) the trophy hunters and illegal large predator theriociders.

\section{(1). Reptile traffickers}

Of the cases involving trafficking in live CITES-listed reptiles (one case also included amphibians and birds), thirteen of the offenders were male and two were female. The females trafficked two tortoises each. This gender imbalance may suggest that the keeping of reptiles (other than tortoises) may be more attractive to men than to women, or that men will be more inclined to commit a trafficking crime in order to pursue their interest in obtaining a reptile than women will. The large police case file material, mainly concerning the illegal keeping of reptiles in Norway, may also provide indications of the gendered dimension of this crime. The large majority of these cases also involve male offenders, who were usually involved in other crimes in addition to WLT. These cases give reason to suggest that for many, keeping/owning reptiles may be associated with hegemonic masculinity in that reptiles are species that some people fear (Öhman and Mineka 2003). Consequently, men may purchase these animals to show their "courage" and to demonstrate that they are "real" or "true" men. For example, in many of the police case files, there are pictures and video clips of the offenders posing with reptiles-pictures that prove the offenders' engagement with prohibited species; one may suspect that posing with their reptiles helps them enhance their personal image-akin to narcissistic trophy photos (Linnemann 2017), enhancing the posers' "masculinity", or to keeping "dangerous dogs" (Maher and Pierpoint 2011). Therefore, they probably have less interest in what these nonhuman animals can offer of other dimensions.

These other dimensions were highlighted in the interviews with reptile keepers, among whom both men and women were represented. The women and men seemed equally consumed with their reptile "pets." In these interviews, what seemed to characterize their relationship to their reptiles was not only fascination, but also care and respect (Sollund 2019). It is possible, though, that these few interviewees differ from the large number of men in the police case files, who were often involved in and apprehended for other crimes, and therefore were caught with the reptiles.

One woman, who was not involved in other crimes, was fined for keeping a snake illegally and stood out in the case file material; she expressed her genuine sorrow when the snake, a boa constrictor, was taken away from her to be killed, calling the snake by her name, "Lisa", and referring to her as "her baby". The case file offenders may or may not be representative of reptile owners; otherwise law abiding reptile keepers could, prior to the ban, pursue their hobby in a more clandestine way, with less risk of being detected than those who had already attracted the attention of police. Overall, based on my interviews with reptile keepers, it appeared that both men and women had trafficked reptiles to Norway. So, while the case file material (and also to some extent the confiscation reports) may indicate that the keeping of reptiles for men may serve as a tool through which they instrumentally increase their masculinity capital, this may perhaps only be a valid currency within specific subcultures, wherein men with criminal inclinations also keep reptiles (that were previously illegal). In order to assess this empirically, one would need to interview men and women in different social environments to explore what meaning the reptiles hold for them.

As noted at the outset, what it means to be "masculine" varies: there is not one normative masculinity, they vary within societies, within different subcultures, social strata etc. As emphasised by Connell and Messerschmidt (2005), hegemonic masculinity is relational. What is expressed through body language, for example, will be understood and responded to based on specific social contexts. What one subcultural group may regard as acceptable, admired or expected, may, in another group, be condemned. 
Although the large majority of the trafficking offenders are male, this may, as suggested above, be coincidental in that it may represent only that men are less risk-adverse than women, and consequently more inclined to commit crimes, whether they involve live nonhuman animals or other categories of crime. That said, willingness to accept risk could, perhaps, also be a certain feature of hegemonic masculinity whereby bravery and taking chances is socially applauded. ${ }^{27}$ For example, in a study on the effects of gender difference on the inclination to commit crime, Lagrange and Silverman (1999) found that: "low self-control ... differs between males and females. This, in turn, implies that there may be different patterns of causality leading to male and female offending. In addition, the most important variable overall in terms of explaining gender differences is a preference for risk seeking."

\section{(2). Animal products and collecting}

This category of offenders is motivated by collecting; these are offenders who purchase items, such as ivory or stuffed nonhuman animals, including large birds of prey, on the internet, and who collect birds' eggs, which they may abduct themselves or buy from others. Collecting per se may not be particular for any gender, but what the individual collects may have gendered aspects. Two collector cases from my data deserve specific mention in this regard. One man was caught trafficking 264 dead nonhuman animals-24 of whom were listed in the appendices of CITES and the Bern Convention, including bears, buzzards, gyrfalcons, hawks, kestrels, lynx, marsh harriers, owls, red kits, turtles and wolves. Another man was caught and convicted mainly for trafficking in ivory (see (Sollund 2016, 2019), for a more thorough analysis of the case and the verdicts). When police and customs searched his house, they found a collection of ten thousand dead, stuffed nonhuman animals, as well as heads, pelts, and skins.

One may link gender to collecting through the gendered meaning of essential collecting activities, the gender associations of the objects collected and the gendered uses of collections (Belk and Wallendorf 1994, p. 241). As mentioned, while collecting per se is neither typically male nor female, the character of the object collected may have masculine or feminine dimensions to it. While girls may collect decorative objects (e.g., flowers, napkins), dolls and doll items, personal referent objects (e.g., souvenirs, autographs, valentines) and jewellery, boys may be more inclined to collect action figures, cars, nonhuman animal and insect parts, saleable junk, objects of war, hunting or fishing objects, and sports memorabilia (Belk and Wallendorf 1994).

According to Belk and Wallendorf (1994), when people collect, the objects in a collection are deemed sufficiently significant that they are removed from the category of the ordinary and treated as extraordinary. When a nonhuman animal or the part of a nonhuman animal is brought into a house, the nonhuman animal ceases to be a free live individual and becomes an "it" —an item in a collection. The reason why such nonhuman animals are killed, removed and shipped as objects is that they represent something special that can add more value to the collection. As in most "collections", the more rare, the better (Courchamp et al. 2006). Belk and Wallendorf (1994, p. 240) also note that "because a collection results from purposeful acquisition and retention, it announces identity traits with far greater clarity and certainty than the many other objects owned. Collections are especially

27 This observation can, however, be critiqued for regarding such edgework as a representation of hegemonic masculinity, precisely because this kind of activities are chosen to be regarded as "masculine", thus failing to encompass a gendered analysis opening up for other kinds of risk taking edgework performed by women, whether within or outside the law. The analysis can thus, perhaps, be accused of being tautological. My purpose here is not to undertake a gender analysis of "edgework" and other risk-related activities and behavior. As such, I leave the discussion about whether edgework is always, or even usually, an expression or performance of masculinity to another day. I support Newmahr (2011) view, however, that the values that we currently understand as the "edginess" of edgework are enshrined in narratives of hegemonic masculinity. "Edgework" is thus constrained by the same "maleness of philosophy" (Newmahr 2011, p. 686). Whether the risk of committing a crime (involving nonhuman animals or otherwise) is equally appealing to both men and women, but less transparent because the law enforcement agencies generally focus on men, will be omitted from this article. 
instrumental to identity among avid collectors." Gender is perhaps the most important identity marker in a person, thus, collecting is a means of achieving, expressing, and enhancing gender identity.

Through collections, nonhuman animals are "tamed"- they are "conquered, captured and hung on the wall" (Belk and Wallendorf 1994). In addition, the collections may compensate for something that is lacking in a person's life. For example, in the case involving the man with the collection of ten thousand nonhuman animals, the man had had to leave his (masculine) job as a deep-sea diver in the early Norwegian oil bonanza because of a work-related illness. He then began dedicating all his time to his collection and to collecting activities, feverishly engaging in eBay auctions on the internet (see Sollund 2016, 2019).

\section{(3). Trophy hunting/illegal predator killings}

If a hunter can boast of having killed a nonhuman animal himself, the more valuable the collection since it can document his will and capability of winning the "battle" against nature (Kheel 2008) ${ }^{28}$. While trophy hunting of "exotic" nonhuman animals may be reserved for people with the economic resources to travel to distant locations (such as Africa) to kill an endangered nonhuman animal, and then for the shipping of its remains back home, the (trophy) hunting of domestic nonhuman animals can be accomplished by men from various social layers of society. In Norway, offenders tend to have lower income levels, live in rural areas, and be associated with farming and animal husbandry. There are thus different types of hunting theriocides connected to trophies: the trophy hunting by wealthy Westerners, often in canned hunts, wherein animals like lions are bred and raised in captivity and then released into another enclosure to be shot, and the rural hunter who will hunt legally and illegally as part of a cultural tradition.

Eco-feminists critique the elevation of masculine values and traits, for example, the masculine notion that killing animals in a hunt is "noble" (see Kheel 2008), rather than seeing it for the act of violence it is (Sollund 2019). Women may turn to hunting because of a desire to be on par with men or to embody male values that are elevated in society rather than the denigrated feminine values.

Whether rich or poor, the hunters may have similar motivations, however, they may also have different features. The rich trophy hunter adds another dimension to his "manhood" when he travels to kill: the power that comes with wealth. While the rural hunter may not engage in hunting to flaunt his socioeconomic status, he may take pride in living in close proximity to nature and killing and eating the creatures that live there. His attitudes may, however, also be regarded as alienation from and disrespect for the nonhuman animals who live there. For the rich trophy hunter who travels far and wide in order to kill the "big five" in foreign countries, his alienation to nature seems even bigger, since what he is doing is often mere executions because he is hunting nonhuman animals raised for the purpose of being executed, rather than killing free-born animals in "battle" with nature. ${ }^{29}$ For example, a media mogul in Norway, whose collection I witnessed when I picked up my daughter at a birthday party at a classmates' house when she was little, illustrates these expressions of power. The man's collection contained crocodiles, a polar bear, three big cats, including a leopard, and a large number of birds of prey. The hunter himself has said in media interviews that he went hunting frequently, and his stories included killing a black bear in Alaska and a lion in Africa. Regarding the lion, he boasted that in the village near where he shot him, the people were so happy he had killed the "dangerous lion" that they carried him around in triumph, thus exemplifying a typical neo-colonial practice of trophy hunting mentioned above (see Wall and McClanahan 2015). The man idolized Ernest Hemingway, for the ways in which he "lived out the 'man' in himself." By killing animals, especially endangered predator species, he enhanced (a) his collection; (b) his reputation as a hunter; (c) his self-awareness in terms of ideals of masculinity and (d) the thrill of the moment.

28 It is worth noting that hunting may take on various forms and meanings depending largely on cultural context.

29 See, for example, https://www.theguardian.com/environment/2013/jun/03/canned-hunting-lions-bred-slaughter. 
To hunt demands that the animal is objectified and othered (Sollund 2016, 2017b; White 2016). Hunting, whether legal or illegal, does not take place in a social vacuum, and the undergirding of the norms and values of the hunting subculture is important (Nurse 2015), as is the more general normative climate that favours hunting (Sollund 2015, 2016, 2017b). One can therefore assume that the media mogul's peers shared some of his hegemonic masculinity ideals. Living in a modern urban society with desk jobs perhaps makes it even more important for some men to engage in traditional hegemonic ideals of masculinity. The collecting of trophies shows the man's prowess in subjugating nature (nonhuman animals), thus enlarging his sense of power and masculinity (Fine 2000; Gaard 1993; Kheel 2008). The trophies provide and prove a particular sort of wealth, increasing his male social capital (Bourdieu 1995).

With respect to rural theriociders, Fine (2000, p. 816) notes that for hunters in Michigan in the United States, "there is no question that many men who took (and take) to hunting did so because it was considered one of the few remaining authentically masculine and white, male-only activities left in a feminized and integrated world." Such motivation may be of particular importance for men from lower, rural social strata of Norwegian society (see Skogen et al. 2013), who for different reasons may feel disempowered. Important decisions concerning their lives and livelihoods are made centrally, such as those concerning the protection of endangered species that may make their sheep-herding difficult, in addition to depriving them of their traditional "right" to hunt with a dog because the wolves may constitute a risk to the free running dogs (Skogen 2001). As discussed by Von Essen et al. (2014), the illegal killing of endangered predators may thus be a crime of dissent, a response to being disempowered by central authorities (see also Hagstedt and Korsell 2012; Nurse 2015). However, more than a crime of dissent, it is also an expression of hegemonic masculinity whereby the act of violence constituted by the hunt represents a means to a sensation of regaining control, in a life situation in which they feel disempowered. Concerning other violence committed by men, for example, such as homicide and rape, it is documented that being subject to social isolation and marginalisation, and a feeling of being powerless and emasculated, can entail the use of violence as a means by which a sense of empowerment, control and masculinity is regained (Sollund 2001).

\section{Minority Masculinities in a Centralised Femocracy}

In a case before the Norwegian Supreme Court in 2015 the main offender was convicted of killing a wolf (and for attempts to kill a family group) and received a sentence of one year in prison, while the second offender was sentenced to six months imprisonment, the third offender to five months, and the fourth offender to four months (see Sollund 2017b). All lost hunting rights for three years (Sollund 2017b). In the subculture of the above offenders, they too enhance the relational aspects of hegemonic masculinity through the subcultural socialising when the nonhuman animals are hunted (see also Bye 2003; Skogen 2001). Thereby they increase their social identity as hunters, and their social status among their significant others, in constructing the normative climate for masculinity that permits them to illegally kill nonhuman animals pertaining to endangered species.

The main offender had fourteen wolves tattooed on his arm, each representing a wolf he had killed. ${ }^{30}$ This may also be perceived as a way of collecting trophies. Rather than keeping the carcasses, which may be risky because the wolves are protected by law, he transferred the trophies to his body. Thus, he made the illegal theriocides a physical part of him and a stronger expression of his personal and social identity, thereby bringing him status among his peers. Being part of a subculture in a community where the general normative climate includes a hostility to the wolves and state predator management, such individuals encounter few informal social controls when it comes to hunting. Quite the contrary,

30 Personal communication with another researcher, whom I have chosen to keep anonymous. This information was revealed during a police investigation, and the other researcher was informed about this in an interview with the police investigators of the case. 
in fact, as the few people who want to have wolves and other protected predators in their nearby forests are silenced with threats and harassment ${ }^{31}$. These silenced voices may also represent counter masculinities that, being in the minority, are oppressed by the hunters. What may be recognized as the "accepted" hegemonic masculinity in Norway, with a well-established and functioning "femocracy" 32 , is a "softer" masculinity than that which governs in rural areas, where more traditional gender roles and masculinities may dominate. Hence, in such areas, the kind of masculinity expressed by the killing (illegally) of the wolf may be exaggerated, both as a protest against urban, centralized decisions impacting how they can live their lives and express their masculinity through hunting and farming, but also as a protest against the gender equality ideals that are condoned by the state.

Indeed, Norwegian society exhibits a good degree of gender equality in that it is acceptable for men to parent and for women to be leaders. For some men, however, and perhaps especially for men belonging to the working class, gender equality may be experienced as having gone too far. As Connell puts it, "Many men resist change, because of the 'dividend' they get from patriarchal gender systems" (p. 19). Thus, many men experience the gradual loss of arenas where they could perform traditional masculine ideals (such as demonstrating control over nature through killing animals), carrying weapons, being in company with only men where they can employ sexist jargon otherwise unaccepted in society, and so forth. For this category of men, killing an endangered animal may be a way to compensate for bygone era and a position of status to which they were previously entitled, simply by virtue of being men.

There are several other reasons why killing an endangered animal may be appealing. First, wolves are often hated by farmers and hunters (Hagstedt and Korsell 2012; Sollund 2016) because they allegedly "compete" with hunters for prey and also constitute a threat to their hunting dogs and hunters' therioristic lifestyles. Second, among hunters, killing a wolf enhances one's social status (Hagstedt and Korsell 2012), just like the trophy hunter who killed the lion. This, in turn, is connected to ideals of masculinity: conquering nature through killing large predators, demonstrating the ability to overpower others, and engaging in thrill-seeking through which killing becomes a form of entertainment and a leisure activity (Nurse 2015; Sollund 2015, 2016, 2017b; White 2016). Hunting may also constitute a kind of male comradery - and an enhanced sense of masculinity — when undertaken in groups (Brandth and Haugen 2006; Bye 2003; Kheel 2008; Presser and Taylor 2011, p. 488).

\section{Concluding Discussion}

This article has demonstrated that men are highly overrepresented in WLT and hunting-related crimes, but categorizing crime as a masculine activity may be a simplification. Collier (1998, p. 840) criticizes the concept of hegemonic masculinity through its typical use in accounting for violence and crime: "Hegemonic masculinity came to be associated solely with negative characteristics that depict men as unemotional, independent, nonnurturing, aggressive, and dispassionate-which are seen as the causes of criminal behaviour." Connell and Messerschmidt (2005) thus note that men's behaviour becomes reified in a concept of masculinity that then, in a bit of circular reasoning, becomes the explanation (and the excuse) for the behaviour. By claiming that reptile-keeping and trafficking and hunting crimes are expressions of hegemonic masculinity, one risks labelling men as brutal criminals while reaching no closer to an explanation of why these crimes are more prevalent among men than among women. However, turning to such actions may be facilitated by the repertoire available in such subcultures and contexts, i.e., implying that it is "tough and masculine" to keep reptiles and that "'real men' hunt". This may be regarded not only as an available choice of action, but as a prescript for action.

The hunting and killing of nonhuman animals and the collecting of nonhuman animals' parts may represent one of the last bastions of men to exercise "traditional, hegemonic masculinity." As gender

31 https://www.gd.no/nyheter/ulv/hedmark/pensjonist-fra-rena-taler-ulvens-sak-i-retten/s/5-18-649072.

32 A concept signifying the implementation of gender equality measures by the state. 
is a system of social relations and patterns of social practice associated with the position of men in any society's set of gender relations (Connell and Messerschmidt 2005), there is, consequently, not just one masculinity. One must assume that within group/subcultures, specific norms of what kind of masculinities may be enacted will determine the space each individual will have for choosing how to perform his masculinity. The smaller the group or social network of a person, the more limited will be his available repertoire of action, the more limited the eligibility of his masculinity. If a person is unable to leave his social context, the person may follow the norms of masculinity that are available within that social setting, such as a subculture with an affinity for killing free born nonhuman animals. This may often be the case with Norwegian farmers/hunters with long roots in a particular geographical context and with a limited number of persons to relate to. Therefore, not only can there be various hegemonic masculinities in a society like the Norwegian, but they may also vary within the same local community. The more homogenous the culture, the less opportunity there will probably be for the enactment of various (relational) masculinities, meaning that those who oppose the killing of endangered predators in their community will be silenced. This, however, does not mean that the subcultures determine them to act according to such ideals, it is also a matter of choice and priorities.

This article has also demonstrated that concerning hunting, whether legal and or illegal and whether or not for trophies, such practices may also indicate the inertia in habitus (Bourdieu 1995) and that it takes time for people to adopt new norms and (embodied) practices. Thus, when men are convicted for illegal theriocides, and claim self-defense or emergency rights to prevent attacks on their nonhuman animal property (and capital), they are also enacting and perpetuating antiquated notions of masculinity. Thereby they may protect their lifestyle with millennia long traditions (Nibert 2013; Noske 1989), and their masculinity. Due to a limited social network, these men fail to incorporate changes in habitus, which imply different notions of what it means to be a man in in a modernized society like Norway, where attitudes towards women and nonhuman animals, as reflected in the growing animal rights and environmental movements, have been changing.

Collecting "wildlife", engaging in reptile-trafficking and keeping and hunting may also reflect a sense of social exclusion and marginalisation from other aspects of society. Such men may thereby increase their social standing among peers who share similar feelings, which again will strengthen such (antiquated) hegemonic ideals of masculinity within these subcultures, and create an even greater divide between the centralised values of a femocratic society which purports to be concerned with environmental issues (Sollund et al. 2019; Sollund and Runhovde 2020).

The concept of hegemonic masculinity has helped in theorizing the relationship among masculinities and a variety of crimes (Newburn and Stanko 2013) and has also been employed in studies of specific crimes committed by boys and men, such as rape in Switzerland, murder in Australia, football hooliganism and white-collar crime in England, and violent assault in the United States (Connell and Messerschmidt 2005). As this article has shown, gender theory and ecofeminist perspectives are also valuable tools for discussing other crimes of urgent importance-those involving free born animals who, as victims of human action, suffer harm and face extinction in large numbers. More research needs to be undertaken, however, to understand further whether the majority of "wildlife' crimes are committed by men in other locations, whether these are connected to ideals of hegemonic masculinity, and how they are interpreted in those specific social contexts.

Funding: This research received no external funding.

Conflicts of Interest: The author declares no conflict of interest. 


\section{References}

Adams, Carol. 1996. Caring about suffering: Feminist exploration. In Beyond Animal Rights: A Feminist Caring Ethic for the Treatment of Animals. Edited by Carol Adams and Josephine Donovan. New York: Continuum, pp. 170-97.

Beirne, Piers. 2014. Theriocide: Naming Animal Killing. International Journal for Crime, Justice and Social Democracy 3: 49-66. [CrossRef]

Belk, Russell W., and Melanie Wallendorf. 1994. Of Mice and Men: Gender Identity in Collecting i Interpreting Objects and Collections. Edited by Susanne M. Pearce. Abingdon: Routledge.

Bourdieu, Pierre. 1995. Outline of a Theory of Practice. Cambridge: Cambridge University Press.

Brandth, Berit, and Marit S. Haugen. 2006. Changing masculinity in a changing rural industry: Representations in the forestry press. In Country Boys: Masculinity and Rural. University Park: The Pennsylvania State University Press, pp. 217-33.

Burgess-Proctor, Amanda. 2006. Intersections of Race, Class, Gender, and Crime: Future Directions for Feminist Criminology. Feminist Criminology 1: 27-47. [CrossRef]

Bye, Linda Marie. 2003. Masculinity and Rurality at Play in Stories About Hunting. Norsk Geografisk Tidsskrift-Norwegian Journal of Geography 57: 145-53. [CrossRef]

Collier, Richard. 1998. Masculinities, Crime and Criminology. Thousand Oaks: Sage.

Connell, Raewyn. 2005. Masculinities. Berkeley: University of California Press.

Connell, Raewyn, and James Messerschmidt. 2005. Hegemonic Masculinity: Rethinking the Concept. Gender $\mathcal{E}$ Society 19: 829-59.

Courchamp, Frank, Elena Angulo, Phillipe Rivalan, Richard Hall, Laetitia Signoret, Leigh Bull, and Yves Meinard. 2006. Rarity Value and Species Extinction: The Anthropogenic Allee Effect. PLoS Biology 4: e415. [CrossRef] [PubMed]

De Beauvoir, Simone, and Howard Parshley. 1953. The Second Sex. New York: Random House.

Donovan, Josephine, and Carol Adams, eds. 1996. Beyond Animal Rights: A Feminist Caring Ethic for the Treatment of Animals. New York: Continuum.

Duffy, Rosaleen. 2000. Killing for Conservation: Wildife Policy in Zimbabwe. Bloomington: Indiana University Press.

Fine, Lisa M. 2000. Rights of Men, Rites of Passage: Hunting and Masculinity at Reo Motors of Lansing, Michigan, 1945-1975. Journal of Social History 33: 805-23. [CrossRef]

Gaard, Greta. 1993. Living Interconnections with Animals and Nature. In Ecofeminism: Women, Animals, Nature. Edited by Greta Gaard. Philadelphia: Temple University Press, pp. 1-13.

Gålmark, Lisa. 2008. Aristotle Revisited: Anthro-Andocentrism and Meat Normativity. In Harms: Ecological Crime and Speciesism. Edited by Ragnhild Sollund. New York: Nova Science Publishers, pp. 87-108.

Gålmark, Lisa. 2016. Revolutionens Rosenvatten [The Rosewater of the Revolution]. Stockholm: Dela Förlag.

Goyes, David R., and Ragnhild Sollund. 2016. Contesting and Contextualising CITES: Wildlife Trafficking in Colombia and Brazil. International Journal for Crime, Justice and Social Democracy 5: 87-102. [CrossRef]

Hagstedt, Johanna, and Lars Korsell. 2012. Unlawful Hunting of Large Carnivores in Sweden. In Eco-Global Crimes: Contempory Problems and Future Challenges. Edited by Rune Ellefsen, Ragnhild Sollund and Guri Larsen. Farnham: Ashgate, pp. 209-32.

Haraway, Donna. 1988. Situated Knowledges: The Science Question in Feminism and the Privilege of Partial Perspective. Feminist Studies 14: 575-99. [CrossRef]

Harding, Sandra, ed. 2004. Introduction. In The Feminist Standpoint Theory Reader: Intellectual and Political Controversies. New York: Routledge, pp. 1-16.

Joseph, Janice. 2010. The Plight of Female Migrant Domestic Workers in the Gulf States. In Who Pays the Price? Foreign Workers, Society, Crime and the Law. Edited by Mally Shechory, Sarah Ben-David and Dan Soen. New York: Nova Science Publishers, pp. 225-40.

Kheel, Marti. 2008. Nature Ethics: An Ecofeminist Perspective. Lanham: Rowman \& Littlefield Publishers.

Lagrange, Teresa C., and Robert Silverman. 1999. Low Self-Control and Opportunity: Testing the General Theory of Crime as an Explanation for Gender Differences in Delinquency. Criminology 37: 41-72. [CrossRef]

Lane, Pauline. 1998. Ecofeminism Meets Criminology. Theoretical Criminology 2: 235-48. [CrossRef]

Leberatto, Antony. 2016. Understanding the Illegal Trade of Live Wildlife Species in Peru. Trends in Organized Crime 19: 42-66. [CrossRef] 
Liberg, Olof, Guillaume Chapron, Petter Wabakken, Hans Christian Pedersen, Thompson Hobbs, and Hakan Sand. 2012. Shoot, Shovel and Shut Up: Cryptic Poaching Slows Restoration of a Large Carnivore in Europe. Proceedings of the Royal Society of Biological Sciences 279: 910-15. [CrossRef] [PubMed]

Linnemann, Travis. 2017. Proof of Death: Police Power and the Visual Economies of Seizure, Accumulation and Trophy. Theoretical Criminology 21: 57-77. [CrossRef]

Lynch, Michael, and Paul Stretsky. 2003. The Meaning of Green: Contrasting Criminological Perspectives. Theoretical Criminology 7: 217-38. [CrossRef]

Maher, Jennifer, and Harriet Pierpoint. 2011. Friends, Status Symbols and Weapons: The Use of Dogs by Youth Groups and Youth Gangs. Crime, Law and Social Change 55: 405-20. [CrossRef]

Maher, Jennifer, and Ragnhild Sollund. 2016. Law Enforcement of the Illegal Wildlife Trade: A Comparative Strengths, Weaknesses, Opportunities and Threats [SWOT] Analysis of the UK and Norway. Journal of Trafficking, Organised Crime and Security 2: 82-99.

McCall, Leslie. 2005. The Complexity of Intersectionality. Signs: Journal of Women in Culture and Society 30: 1771-800. [CrossRef]

Newburn, Tim, and Elizabeth Stanko. 2013. Just Boys Doing Business? Men, Masculinities and Crime. London: Routledge.

Newmahr, Staci. 2011. Chaos, Order, and Collaboration: Toward a Feminist Conceptualization of Edgework. Journal of Contemporary Ethnography 40: 682-712. [CrossRef]

Nibert, David. 2002. Animal Rights/Human Rights: Entanglements of Oppression and Liberation. Lanham: Rowman \& Littlefield Publishers.

Nibert, David. 2013. Animal Oppression and Human Violence: Domesecration, Capitalism, and Global Conflict. New York: Columbia University Press.

Noske, Barbara. 1989. Humans and Other Animals: Beyond the Boundaries of Anthropology. London: Pluto Press.

Nurse, Angus. 2015. Policing Wildlife: Perspectives on the Enforcement of Wildlife Legislation. London: Palgrave MacMillan.

Öhman, Arne, and Susan Mineka. 2003. The Malicious Serpent Snakes as a Prototypical Stimulus for an Evolved Module of Fear. Current Directions in Psychological Science 12: 5-9. [CrossRef]

Presser, Lois, and William V. Taylor. 2011. An autoethnography of hunting. Crime, Law and Social Change 55: 483-94. [CrossRef]

Runhovde, Siv R. 2015. Seizures of Inconvenience? Policy, Discretion and Accidental Discoveries in Policing the Illegal Wildlife Trade at the Norwegian Border. Crime, Law and Social Change 64: 177-92. [CrossRef]

Schneider, Jacqueline. 2012. Sold into Extinction: The Global Trade in Endangered Species. Santa Barbara: Praeger.

Seeberg, Mary Louise. 2012. Exploring Intersectionality, Systems and Capitals: The Case of a Filipino Nurse in Norway. In Transnational Migration, Gender and Rights. Edited by Ragnhild Sollund. Bingley: Emerald Publishing Limited.

Skogen, Ketil. 2001. Who's Afraid of the Big, Bad Wolf? Young People's Responses to the Conflicts over Large Carnivores in Eastern Norway. Rural Sociology 66: 203-26. [CrossRef]

Skogen, Ketil, Olve Krange, and Helene Figari. 2013. Ulvekonflikter. En Sosiologisk Studie. [Wolfe Conflicts. A Sociological Study]. Oslo: Akademika.

Smart, Carol. 2013. Women, Crime, and Criminology: A Feminist Critique. London: Routledge.

Sollund, Ragnhild. 2001. Political refugees' violence in Norway. Journal of Scandinavian Studies in Criminology and Crime Prevention 2: 84-103. [CrossRef]

Sollund, Ragnhild. 2008. Causes for Speciesism: Difference, Distance and Denial. In Global Harms: Ecological Crime and Speciesism. Edited by Ragnhild Sollund. New York: Nova Science Publishers, pp. 109-31.

Sollund, Ragnhild. 2011. Expressions of Speciesism: The Effects of Keeping Companion Animals on Animal Abuse, Animal Trafficking and Species Decline. Crime, Law and Social Change 55: 437-51. [CrossRef]

Sollund, Ragnhild. 2012a. Speciesism as Doxic Practice Versus Valuing Difference and Plurality. In Eco-Global Crimes: Contempory Problems and Future Challenges. Edited by Rune Ellefsen, Ragnhild Sollund and Guri Larsen. Farnham: Ashgate, pp. 209-32.

Sollund, Ragnhild. 2012b. Oil Production, Climate Change and Species Decline: The Case of Norway. In Climate Change from a Criminological Perspective. Edited by Rob White. New York: Springer, pp. 135-47.

Sollund, Ragnhild. 2013a. Animal Trafficking and Trade: Abuse and Species Injustice. In Emerging Issues in Green Criminology: Exploring Power, Justice and Harm. Edited by Reece Walters, Diane Westerhuis and Tanya Wyatt. Basingstoke: Palgrave, pp. 72-92. 
Sollund, Ragnhild. 2013b. The Victimization of Women, Children and Non-Human Species through Trafficking and Trade: Crimes Understood Through an Eco-Feminist Perspective. In Routledge International Handbook of Green Criminology. Edited by Nigel South and Avi Brisman. London: Routledge, pp. 317-31.

Sollund, Ragnhild. 2015. With or Without a License to Kill: Human-Predator Conflicts and Theriocide in Norway. In Environmental Crime and Social Conflict: Contemporary and Emerging Issues. Edited by Avi Brisman, Nigel South and Rob White. Surrey: Ashgate, pp. 95-125.

Sollund, Ragnhild. 2016. The Animal Other: Legal and Illegal Theriocide. In Greening Criminology in the 21st Century. Edited by Matthew Hall, Tanya Wyatt, Nigel South, Angus Nurse, Gary Potter and Jennifer Maher. London: Routledge, pp. 93-113.

Sollund, Ragnhild. 2017a. Doing Green, Critical Criminology with an Auto-Ethnographic, Feminist Approach. Critical Criminology: An International Journal 25: 245-60. [CrossRef]

Sollund, Ragnhild. 2017b. Perceptions and Law Enforcement of Illegal and Legal Wolf Killing in Norway: Organized Crime or Folk Crime? Palgrave Communications 3: 17059. [CrossRef]

Sollund, Ragnhild. 2019. The Crimes of Wildlife Trafficking: Issues of Justice, Legality and Morality. Abingdon and New York: Routledge.

Sollund, Ragnhild Aslaug, and Siv Rebekka Runhovde. 2020. Responses to wildlife crime in post-colonial times. Who fares best? The British Journal of Criminology. [CrossRef]

Sollund, Ragnhild, Angela M. Maldonado, and Claudia Brieva Rico. 2019. The Norway-Colombia Agreement to Protect Rainforest and Reduce Global Warming: Success or Failure? International Journal for Crime, Justice and Social Democracy 8: 56-73. [CrossRef]

Taylor, Nik, and Amy Fitzgerald. 2018. Understanding Animal (Ab)use: Green Criminological Contributions, Missed Opportunities and a Way Forward. Theoretical Criminology 22: 402-25. [CrossRef]

Trouwborst, Arie, Floor Fleurke, and John Linnell. 2017. Norway's Wolf Policy and the Bern Convention on European Wildlife: Avoiding the "Manifestly Absurd". Journal of International Wildlife Law E Policy 20: 155-67.

Van Uhm, Dan. 2016. The Illegal Wildlife Trade: Inside the World of Poachers, Smugglers and Traders. New York: Springer. Von Essen, Erica, Hans Peter Hansen, Helena Nordström Källström, M. Nils Peterson, and Tarla Rai Peterson. 2014. Deconstructing the Poaching Phenomenon: A Review of Typologies for Understanding Illegal Hunting. The British Journal of Criminology 54: 632-51. [CrossRef]

Wall, Tyler, and Bill McClanahan. 2015. Weaponising Conservation in the 'Heart of Darkness': The War on Poachers and the Neocolonial Hunt. In Environmetnal Crime and Social Conflict: Cotemporary and Emerging Issues. Edited by Avi Brisman, Nigel South and Rob White. Surrey: Ashgate, pp. 221-38.

White, Rob. 2016. Inter-species violence: Humans and the harming of animals. In Australian Violence, Crime, Criminal Justice and Beyond. Edited by Stubbs Julie and Tomsen Stephen. Alexandria: The Federation Press.

White, Rob. 2018. Green Victimology and Non-Human Victims. International Review of Victimology 24: 1-17. [CrossRef]

Wyatt, Tanya. 2011. Illegal Raptor Trade in the Russian Federation. Contemporary Justice Review 14: 103-23. [CrossRef]

Wyatt, Tanya. 2013. Illegal Wildlife Trade: A Deconstruction of the Crime, the Offenders and the Victims. London: Palgrave.

(C) 2020 by the author. Licensee MDPI, Basel, Switzerland. This article is an open access article distributed under the terms and conditions of the Creative Commons Attribution (CC BY) license (http://creativecommons.org/licenses/by/4.0/). 